\title{
Analisis Efektivitas Biaya Penggunaan Obat Antiretroviral Atripla dan T/H/A pada Pasien HIV Rawat Inap RSUD Raden Mattaher Provinsi Jambi Tahun 2017-2018
}

\section{Cost-Effectiveness Analysis of Antiretroviral Atripla and T/H/A Treatments in Inpatient HIV Patients at Raden Mattaher Hospital Jambi during 2017-2018}

\author{
Jelly Permatasari, Disty Aldila Wicaksono*, Medi Andriani \\ Program Studi Farmasi, Stikes Harapan Ibu Jambi \\ Jl. Tarmizi Kadir No.71, Pakuan Baru, Kecamatan Jambi Selatan, \\ Kota Jambi 36132, Indonesia \\ *Corresponding author email: disty.aldila1992@gmail.com
}

Received 27-03-2020 Accepted 10-07-2020 Available online 30-07-2020

\begin{abstract}
ABSTRAK
Human Immunodeficiency Virus (HIV) telah manjadi masalah darurat global. HIV merupakan penyakit kronis yang membutuhkan pengobatan seumur hidup. Infeksi yang disebabkan oleh HIV ini dapat menurunkan sistem kekebalan tubuh sehingga menimbulkan infeksi oprtunistik pada penderita. Infeksi opurtunistik tersebut dapat memperpanjang lama rawatan pada penderita, sehingga menambah biaya pengobatan HIV. Penelitian ini merupakan studi farmakoekonomi. Sampel diperoleh dari data rekam medis pasien HIV rawat inap tahun 2017-2018 yang memenuhui kriteria inklusi yang diambil secara purposive sampling. Sampel yang memenuhi kriteria inklusi berjumlah 24 orang. Persentase kelompok usia pasien 17-25, 26-35, 36-45, dan 46-55 tahun masing-masing sebesar 33,33; 33,$33 ; 29,17$; dan $4,17 \%$. Persentase jenis kelamin laki-laki dan perempuan masing-masing 54,17 dan $45,83 \%$. Pekerjaan pasien meliputi wiraswasta $(41,67 \%)$, IRT $(41,67 \%)$, petani $(8,33 \%)$, pegawai swasta $(8,33 \%)$. Persentase lama rawatan $<9$ hari dan $>9$ hari masingmasing sebesar 83,33 dan 16,67\%. Antiretroviral (ARV) yang digunakan adalah atripla (EFV $600 \mathrm{mg}$, AZT $300 \mathrm{mg}$, TDF $300 \mathrm{mg}$ ) dan T/H/A (kombinasi TDF $300 \mathrm{mg}$, hiviral/lamivudine $150 \mathrm{mg}$, dan aluvia (lopinavir/ritonavir $200 \mathrm{mg} / 50 \mathrm{mg}$ )), yaitu sebesar 66,67 dan 33,33\%. Rata-rata biaya medis langsung atripla sebesar Rp1.547.713,00, sedangkan pada T/H/A sejumlah Rp2.962.642,00. Persentase efektifitas atripla adalah 87,5\%, sedangkan T/H/A sebesar 75\%. Nilai incremental cost-effectiveness ratio (ICER) sebesar $-113.194,32$. Analisis efektifitas biaya penggunaan ARV pada pasien rawat inap di RSUD Raden Mattaher Provinsi Jambi pada tahun 2017-2018 menunjukkan bahwa atripla merupakan ARV yang paling efektif secara biaya dan outcome (lama rawat).
\end{abstract}

Kata kunci: analisis efektivitas biaya, atripla, HIV, T/H/A. 


\begin{abstract}
Human Immunodeficiency Virus (HIV) has become a global emergency problem. HIV is a chronic disease requiring lifelong treatment. Infection by HIV decreases the body's immune system and enables opportunistic infections in patients. The opportunistic infection possibly extends the length of stay of patients in hospitals, thereby increases the cost of HIV treatment. This research is a pharmacoeconomic study. Data were retrieved from medical records of 24 inpatients HIV patients met the inclusion criteria in a period of 2017-2018 by purposive sampling. The percentage of age groups of 17-25, $26-35,36-45$, and $46-55$ years were $33.33,33.33,29.17$, and $4.17 \%$, respectively. The percentage of male patients was $54.17 \%$, while that of females was $45.83 \%$. The occupation of the patients was self-employed, housewife, farmer, and private employees with a percentage of 41.67, 41.67, 8.33, and 8.33\%, respectively. The percentage of the length of stay $<9$ days was $83.33 \%$ and that of $>9$ days was $16.67 \%$. The ARVs used were atripla (EFV $600 \mathrm{mg}$, AZT $300 \mathrm{mg}$, TDF $300 \mathrm{mg}$ ) and T/H/A (TDF 300 $\mathrm{mg}$, viral (lamivudine $150 \mathrm{mg}$ ), aluvia (lopinavir/ritonavir $200 \mathrm{mg} / 50 \mathrm{mg}$ )) with the percentage of 66.67 and $33.33 \%$, respectively. The average direct medical costs of atripla were $R p 1,547,713$ and that of $T / H / A$ was $R p 2,962,642$. The percentage of effectiveness of atripla and T/H/A was 87.5 and $75 \%$, respectively. The value of the incremental cost-effectiveness ratio (ICER) was -113,194.32. Atripla was found as the most cost and outcome-effective ARV in the inpatients of Raden Mattaher Hospital in 2017-2018.
\end{abstract}

Key words: atripla, cost effectiveness analysis, $H I V, T / H / A$.

\section{Pendahuluan}

HIV (Human Immunodeficiency Virus) saat ini telah manjadi masalah darurat global. Di seluruh dunia, 35 juta orang hidup dengan terjangkit HIV dan 19 juta orang tidak mengetahui status HIV positif pada diri mereka. Epidemi HIV yang terjadi ini juga menjadi masalah di Indonesia, karena dengan kejadian ini Indonesia merupakan negara urutan ke-5 paling beresiko HIV di Asia. Laporan kasus baru HIV terjadi peningkatan setiap tahunnya (Kemenkes Rl, 2018). Dari data diketahui pada tahun 2016 dilaporkan 41.250 kasus HIV baru dan hingga Maret 2017 dilaporkan 10.376 kasus HIV baru. Secara kumulatif masyarakat Indonesia telah teridentifikasi yang terinfeksi HIV berjumlah 242.699 orang (Ditjen P2P, 2017). Program penanggulangan HIV yang dilakukan oleh pemerintah Indonesia didasari oleh 4 pilar, yang semuanya menuju kepada paradigma zero new infection, zero AIDS-related death dan Zero discrimination. Empat pilar tersebut yaitu pencegahan (prevention), perawatan dukungan dan pengobatan (PDP), mitigasi, dan penciptaan lingkungan yang kondusif. (Kemenkes RI, 2012a).

Terapi menggunakan antiretroviral (ARV) mencangkup bagian yang terbesar dari biaya terapi ARV bagi orang yang hidup dengan HIV. Salah satu penelitian terkait analisis efektifitas biaya penggunaan ARV sudah pernah dilakukan oleh beberapa peneliti yaitu "Cost 
Effectiveness Analysis Penggunaan Obat ARV Kombinasi serta Pengaruhnya terhadap Kualitas Hidup Pasien HIV-AIDS di Poliklinik Rawat Jalan RS Dr. H. Marzoeki Mahdi Bogor", menunjukkan hasil total rata-rata biaya pengobatan pada pasien HIV adalah kombinasi ARV B (tenofovir+lamivudin+efavirenz) yakni sebesar Rp8.113.881,00 sedangkan biaya langsung pada penggunaan obat kombinasi ARV A (zidovudin+lamivudin+nevirapin) yakni sebesar Rp8.229.033,00. Berdasarkan hasil perhitungan unit cost obat kombinasi ARV A lebih baik dari obat kombinasi B, ditandai dengan nilai unit cost yang lebih rendah untuk obat kombinasi $A$ Rp24.413.824,00 dibanding dengan unit cost obat kombinasi B Rp33.773.298,00. $\mathrm{Hal}$ ini merupakan biaya yang sangat besar sehingga diperlukan upaya penanggulangan salah satunya termasuk perhitungan biaya pengobatan HIV di rumah sakit (Hardjadipura et al., 2018).

Atripla (efavirenz $600 \mathrm{mg}$, lamivudine $300 \mathrm{mg}$, tenofovir DF 300 mg) dan T/H/A (tenofovir DF 300 mg, hiviral (lamivudine $150 \mathrm{mg}$ ), aluvia (lopinavir/ritonavir 200 mg/50 mg)) merupakan terapi kombinasi yang banyak digunakan pada pasien HIV yang dirawat inap di RSUD Raden Mattaher sehingga penelitian ini membandingkan dua obat yang paling banyak digunakan oleh pasien HIV rawat inap. Tujuan penelitian ini untuk mengetahui biaya medis langsung dan menganalisis efektivitas obat terhadap biaya pada penggunaan obat antiretroviral atripla dan $\mathrm{T} / \mathrm{H} / \mathrm{A}$ yang ditanggung oleh pemerintah di RSUD Raden Mattaher, Provinsi Jambi. Penerapan kajian farmakoekonomi digunakan untuk membantu para pengambil kebijakan terkait dalam memilih obat secara obyektif yang memiliki efektivitas yang tinggi dengan biaya minimal. Kajian farmakoekonomi yang harus dipertimbangkan adalah faktor klinis (efektivitas) sekaligus faktor ekonomi (biaya) sehingga dapat membantu pemilihan obat yang rasional (Kemenkes $\mathrm{RI}, 2012 b)$.

\section{Metode Penelitian}

Penelitian ini merupakan studi farmakoekonomi dengan data sekunder berupa data rekam medis serta biaya pengobatan dan perawatan pasien di Rawat Inap RSUD Raden Mattaher Provinsi jambi tahun 2017-2018. Penelitian dilaksakan pada Januari 2020 di RSUD Raden Mattaher, Provinsi Jambi. Jumlah dan Cara Pengambilan Sampel

Berdasarkan data rekam medis diperoleh jumlah populasi sebanyak 89 pasien dengan jumlah sampel yang memenuhi kriteria inklusi sebanyak 24 sampel dan teknik pengambilan sampel dilakukan dengan menggunakan teknik purposive sampling. Kriteria inklusi pada penelitian ini sebagai berikut: pasien dengan data rekam medis yang lengkap dan jelas, pasien HIV dengan usia 17-55 tahun, pasien yang mendapatkan terapi ARV atripla dan $T / H / A$, pasien HIV yang dirawat di ruangan interne. Adapun kriterian eksklusi pada penelitian ini adalah pasien HIV yang meninggal tahun 2017-2018. 
Jenis dan Cara Pengumpulan Data

Data yang dikumpulkan adalah data kuantitatif meliputi: perhitungan biaya rata-rata, biaya penggunaan obat HIV pasien rawat inap RSUD Raden Mattaher, Provinsi Jambi, biaya Jasa profesional, biaya pemeriksaan laboratorium, biaya pelayanan kesehatan lainnya serta perhitungan efektivitas terapi obat: lama rawat. Sumber data yang diambil adalah data pasien HIV/AIDS meliputi: rekam medik, daftar harga obat HIV di bagian informasi instalasi farmasi, daftar biaya medik langsung pada ruangan interne RSUD Raden Mattaher, Provinsi Jambi (Andayani, 2013).

Pengolahan dan Analisis Data

Berdasarkan nilai Average Length of Stay (ALOS) ideal tercapainya efektivitas yaitu dengan rata-rata antara 6-9 hari lama rawat (Kemenkes RI, 2011). Indikator efektivitas ditentukan dengan lama rawatan, hal ini dikarenakan memiliki pengaruh terhadap biaya. Analisis data yang diperoleh meliputi analisis univariat digunakan untuk menggambarkan data demografi pasien yaitu frekuensi dari usia pasien, frekuensi dari jenis kelamin, pekerjaan pasien, frekuensi pengguanan obat ARV atripla dan T/H/A. Perhitungan ICER dilakukan dengan rumus sebagai berikut:

$I C E R=\frac{(\text { Rata-Rata Biaya A) }-(\text { Rata-Rata Biaya B) }}{\text { Efektivitas A }- \text { Efektivitas B }}$

Keterangan:

Rata-rata biaya = rata-rata biaya terapi Efektivitas = hasil terapi yang diperoleh
Metode ICER digunakan untuk mengetahui biaya tambahan yang dibutuhkan untuk menghasilkan setiap perubahan satu unit outcome pengobatan.

\section{Hasil dan Pembahasan}

Karakteristik sampel pada penelitian ini dapat dilihat pada Tabel 1. Pada usia 17-45 tahun dapat dikatakan usia pada masa produktif sehingga pada masa ini memiliki aktivitas yang tinggi untuk memiliki perilaku seks beresiko. Pada rentang usia ini individu akan lebih berperan aktif dalam masyarakat dan kehidupan sosial sehingga dapat dipengaruhi oleh pergaulan yang bebas yang membuat mereka terdorong untuk tidak berperilaku secara sehat (Umam et al., 2015).

Kerentanan laki-laki terhadap infeksi HIV dapat disebabkan oleh perilaku negatif yang dilakukan seperti membeli jasa seks komersial, memakai jarum suntik (penasun), dan laki-laki yang mempunyai mobilitas tinggi dan jauh dari pasangannya (Umam et al., 2015). Wanita lebih mudah menjadi HIV/AIDS positif dan lebih terpengaruh dampak buruk epidemik dibandingkan laki-laki karena alasan biologis, sosio-kultur, dan ekonomi. Hal ini terlihat dari hasil yang didapat bahwa persentase pasien HIV wanita tidak terlalu jauh berbeda dengan laki-laki (Departemen Tenaga Kerja dan Transmigrasi, 2005).

Pekerjaan memiliki hubungan yang sangat kuat dengan perilaku beresiko tinggi untuk terinfeksi HIV ibu rumah tangga (IRT) yang dianggap beresiko 
rendah, sebenarnya lebih tinggi transmisinya dari pada pekerja seksual. Hal ini dikarenakan ketidakseragaman gender membuat wanita lebih sulit mengontrol perilaku pasangan. Perilaku dari orangorang pekerja wiraswasta dapat menjelaskan hubungan kerja dengan resiko tertular HIV (Roselinda et al., 2015). Indonesia merupakan negara yang paling rentan terhadap HIV/AIDS yang disebabkan oleh perilaku beresiko pasangan suami/istri. Hal ini dapat dilihat dari data yang ditemukan yaitu wanita dengan status telah menikah. Wanita tertular HIV salah satunya karena alasan biologis. Hal ini terlihat dari data yaitu pekerjaan IRT (Ibu Rumah Tangga) tidak jauh berbeda persentasenya dengan pekerja wiraswasta (Departemen Tenaga Kerja dan Transmigrasi, 2005).

Tabel 1. Demografi pasien

\begin{tabular}{|c|c|c|c|c|}
\hline \multirow{2}{*}{$\begin{array}{c}\text { Karakteristik } \\
\text { Sampel }\end{array}$} & \multicolumn{2}{|c|}{ Atripla } & \multicolumn{2}{|c|}{$T / H / A$} \\
\hline & Jumlah (Pasien) & Persentase (\%) & Jumlah (Pasien) & Persentase (\%) \\
\hline \multicolumn{5}{|l|}{ Umur } \\
\hline $17-25$ & 5 & 20,83 & 1 & 4,17 \\
\hline $26-35$ & 7 & 29,17 & 3 & 12,5 \\
\hline $36-45$ & 4 & 16,67 & 4 & 16,67 \\
\hline $46-55$ & 0 & 0 & 0 & 4,17 \\
\hline \multicolumn{5}{|l|}{ Jenis Kelamin } \\
\hline Laki-Laki & 10 & 41,67 & 3 & 12,5 \\
\hline Perempuan & 6 & 25 & 5 & 20,83 \\
\hline \multicolumn{5}{|l|}{ Pekerjaan } \\
\hline Wiraswasta & 10 & 41,67 & 0 & 0 \\
\hline IRT & 5 & 20,83 & 5 & 20,8 \\
\hline Petani & 0 & 0 & 2 & 8,33 \\
\hline Pegawai & 1 & 4,17 & 1 & 4,17 \\
\hline Swasta & & & & \\
\hline
\end{tabular}

Tabel 2. Analisis efektivitas obat pada pasien HIV pada tahun 2017-2018

\begin{tabular}{clcc}
\hline Nama Obat & Parameter Efektivitas & Efektivitas (Ya/ Tidak) & Jumlah Pasien \\
\hline Atripla & Lama rawatan $<9$ hari & Ya & 14 \\
& Lama rawatan $>9$ hari & Tidak & 2 \\
\hline \multirow{2}{*}{ T/H/A } & Lama rawatan $<9$ hari & Ya & 6 \\
& Lama rawatan $>9$ hari & Tidak & 2 \\
\hline
\end{tabular}

Lama rawatan menjadi salah satu efektivitas dalam pencapaian terapi dan memiliki pengaruh terhadap biaya. Sehingga dapat dikatakan lama rawatan menjadi outcome yang menimbulkan efektivitas dalam terapi dan menjadi indikator pencapaian medis (Citraningtyas et al., 2019). Nilai ALOS idealnya yaitu 
dengan rata-rata antara 6-9 hari (Kemenkes RI, 2011). Pada data ini nilai lama rawatan pasien HIV tahun 2017-2018 lebih banyak <9 hari hal ini termasuk dalam kategori efektif (Kemenkes RI, 2011).

Lama rawatan pasien merupakan indikator penting dalam menentukan keberhasilan terapi pada pasien. Hal ini juga berpengaruh dengan biaya perawatan yang dikeluarkan oleh pasien.
Ini dikarenakan semakin sedikit waktu pasien berada di rumah sakit, maka semakin sedikit/kecil biaya yang dikeluarkan pasien sehingga dapat dikatakan efektif dan efisien pelayanan di rumah sakit (Lubis, 2017). Dengan adanya perpendekan hari rawat inap memungkinkan adanya pengurangan biaya pengobatan yang harus dikeluarkan oleh pasien pada saat pasien di rawat inap (Musnelina et al., 2004).

Tabel 3. Persentase (\%) efektivitas pengobatan pasien HIV pada tahun 2017-2018

\begin{tabular}{cc}
\hline Obat ARV & Persentase (\%) efektivitas \\
\hline Atripla & 87,5 \\
T/H/A & 75 \\
\hline
\end{tabular}

Tabel 4. Perhitungan biaya medis langsung

\begin{tabular}{lcc} 
Jenis Biaya & Atripla (Rp) & T/H/A (Rp) \\
\hline Rawat Inap & 425.250 & 456.750 \\
Rawat IGD & $154.843,75$ & $151.656,25$ \\
Tindakan Inap & 95.900 & 411.225 \\
Radiologi & $66.233,875$ & 57.457 \\
Labor & $435.352,5$ & $477.282,5$ \\
Obat & 340.791 & 1.141 .650 \\
Bank Darah & $21.718,75$ & 251.375 \\
Visit Dokter & 7.623 & 15.246 \\
\hline Total & $1.547 .713,00$ & $2.962 .642,00$ \\
\hline
\end{tabular}

Atripla merupakan terapi kombinasi yang banyak digunakan pada pasien HIV yang dirawat inap di RSUD Raden Mattaher sehingga pengkajian pada terapi kombinasi ini dapat dilihat berdasarkan persentase efektivitas. Pada persentase efektivitas pengobatan pasien HIV, atripla menunjukkan nilai efektivitas yang lebih tinggi dibandingkan dengan T/H/A (Tabel 3). Hal ini dikarenakan atripla memiliki kelebihan yaitu dengan memberikan jadwal pemberian dosis yang nyaman bagi penggunanya/pasien dengan mengkonsumsi jumlah obat yang sedikit yaitu satu tablet dalam satu hari. Dalam hal ini memungkinkan pengguna/pasien 
memiliki kepatuhan yang tinggi terhadap rejimen ini dibandingkan dari terapi $\mathrm{T} / \mathrm{H} / \mathrm{A}$ yang berbasis PI (Protease Inhibitor) umum yang tersedia yang membuat pasien mengonsumsi obat dalam jumlah yang banyak dalam satu hari (Julg \& Bogner, 2008).

Biaya medis penggunaan atripla lebih rendah/relatif murah daripada T/H/A (Tabel 4). Biaya medis sangat penting bagi pasien dan pelayanan kesehatan untuk menjaga kesinambungan pelayanan dan sarana prasarana. Sehingga menjadi acuan pasien dalam pengakumulasian biaya selama masa rawatan. Hal ini juga sangat penting bagi pihak rumah sakit dalam pengelolaan obat yang digunakan jauh lebih efektif dan efisien. Karena rumah sakit dituntut untuk memberikan pelayanan kesehatan kepada masyarakat baik berupa penyediaan barang ataupun jasa tanpa mengutamakan keuntungan dalam melakukan kegiatan yang didasarkan efisiensi dan produktivitas (Suharmiati et al., 2019).

Tabel 5. Perhitungan nilai ICER

\begin{tabular}{cccccc}
\hline $\begin{array}{c}\text { Nama } \\
\text { Obat }\end{array}$ & $\begin{array}{c}\text { Rata-rata biaya medik } \\
\text { langsung (C) (Rp) }\end{array}$ & $\begin{array}{c}\text { Pesentase } \\
\text { Efektivitas (E) }\end{array}$ & $\Delta \mathrm{C}$ & $\Delta \mathrm{E}$ & $\begin{array}{c}\text { ICER } \\
(\Delta \mathrm{C} / \Delta \mathrm{E})\end{array}$ \\
\hline Atripla & 1.547 .713 & 87,5 & -1.414 .929 & 12,5 & $-113.194,32$ \\
T/H/A & 2.962 .642 & 75 & & & \\
\hline
\end{tabular}

ICER merupakan nilai yang menunjukkan biaya tambahan yang dibutuhkan untuk menghasilkan setiap perubahan yang terjadi pada satu unit outcome pengobatan (Khoiriyah et al., 2018). Apabila Nilai ICER yang didapatkan menunjukkan hasil dengan nilai negatif atau semakin kecil, maka ini dapat dijadikan suatu alternatif dalam pemilihan obat tersebut lebih efektif dan lebih efisien, sehingga pilihan terapi tersebut merupakan pilihan yang terbaik untuk digunakan oleh pasien HIV (Citraningtyas et al., 2019).

\section{Simpulan}

Berdasarkan hasil penelitian yang telah dilakukan dapat disimpulkan bahwa untuk mengukur efektivitas berdasarkan lama rawat. Ditentukan dengan Nilai Average Length Of Stay (ALOS) yaitu rata-rata antara 6-9 hari sebagai indikator pencapaian efektivitas. Didapatkan hasil bahwa antiretoviral Atripla memiliki efktivitas yang tinggi dengan biaya yang rendah.

\section{Daftar Pustaka}

Andayani, T.M. 2013. Farmakoekonomi Prinsip dan Metodologi. Yogyakarta: Bursa Ilmu Karangkajen.

Citraningtyas, G., Ruru, R.I., Nalang, A., Ratulangi, U.S. 2019. Analisis efektifitas biaya penggunaan antibiotik sefiksim dan sefotaksim pasien diare di 
Rumah Sakit X tahun 2017. Jurnal Manajemen dan Pelayanan Farmasi, 8(4):145152.

Departemen Tenaga Kerja dan Transmigrasi. 2005. Pedoman Bersama ILO/WHO tentang Pelayanan Kesehatan dan HIV/AIDS. Jakarta: Departemen Tenaga Kerja dan Transmigrasi.

Khoiriyah, S.D., Lestari, K. 2018. Review artikel: kajian farmakoekonomi yang mendasari pemilihan pengobatan di Indonesia. Farmaka, Suplemen 16(3):134145.

Ditjen P2P. 2017. Laporan Situasi Perkembangan HIV-AIDS \& PIMS DI Indonesia. Jakarta: Kementerian Kesehatan RI.

Hardjadipura, E.P., Hasan, D., Winulyo, E.B. 2018. Cost effectiveness analysis penggunaan obat ARV kombinasi serta pengaruhnya terhadap kualitas hidup pasien HIV-AIDS di Poliklinik Rawat Jalan RS Dr. H. Marzoeki Mahdi Bogor. Farmagazine: Jurnal Ilmiah Kefarmasian, 5(3):53-66.

Suharmiati, Handayani, L., Roosihermiatie, B. 2019. Analisis biaya obat unit rawat jalan pada rumah sakit badan layanan umum (BLU)/Badan Layanan Umum Daerah (BLUD) Di Indonesia. Jurnal Kefarmasian Indonesia, 9(2):126-139.

Julg, B., Bogner, J.R. 2008. Atripla ${ }^{\mathrm{TM}}$-HIV therapy in one pill. Therapeutics and Clinical Risk Management, 4(4):573-577.
Kemenkes RI. 2018. Infodatin: Situasi Umum HIV/AIDS dan Tes HIV. file:///C:/Users/HP/AppData/Loc al/Temp/InfoDatin-HIV-AIDS2018.pdf. Data diakses pada 2 Maret 2019.

Kemenkes RI. 2012a. Tatalaksana Klinis Infeksi HIV dan Terapi Antiretoviral. Jakarta: Kemenkes RI.

Kemenkes RI. 2012b. Pedoman Penerapan Kajian Farmakoekonomi. Jakarta: Direktorat Jendral Bina Kefarmasian dan Alat Kesehatan.

Kemenkes RI. 2011. Juknis SIRS Sistem Informasi Rumah Sakit. Jakarta: Direktur Jendral Bina Upaya Kesehatan.

Lubis, I.K. 2017. Analisis length of stay (LOS) berdasarkan faktor prediktor pada pasien DM tipe II di RS PKU Muhammadiyah Yogyakarta. Jurnal Kesehatan Vokasional, 2(2):161-166.

Musnelina, L., Afdhal, A.F., Gani, A., Andayani, P. 2004. Analisis efektifitas biaya pengobatan demam tifoid anak menggunakan kloramfenikol dan seftriakson di Rumah Sakit Fatmawati Jakarta Tahun 20012002. Makara Journal of Health Research, 8(2):59-64.

Roselinda, Wibowo, H.A., Setiawaty, V. 2015. Karakteristik pekerjaan pada kasus human immunodeficiency virus-1 dan artikel riset karakteristik pekerjaan pada kasus human 
immunodeficiency virus-1 dan subtipenya di tujuh provinsi di Indonesia pada tahun 2011. Jurnal Biotek Medisina Indonesia, 4(2):71-76.

Umam, H., Dewi, Y.I., Elita, V. 2015. Identifikasi karakteristik orang risiko tinggi HIV dan AIDS tentang program pelayanan voluntary counseling and testing (VCT). Jurnal Online Mahasiswa Bidang IImu Keperawatan, om 2(1):853-862. 